\title{
The first evaluation of glucose-6-phospate dehydrogenase deficiency (G6PD) gene mutation in malaria endemic region at South Central Timor (SCT) district, Eastern Indonesia 2014-2015
}

\author{
Jontari Hutagalung ${ }^{1 *}$, Hari Kusnanto ${ }^{1}$, Supargiyono ${ }^{2}$, Purwono $^{2}$, Sadewa Ahmad \\ Hamim $^{3}$, Darojatun Ida ${ }^{3}$, Satyagraha Ari Winasti ${ }^{4}$, Novijanti Rintis ${ }^{4}$, Triwibowo
} A. Garjito ${ }^{5}$, Mega Tyas Prihatin ${ }^{5}$, Bai Apris ${ }^{6}$, Bansai Immanuel ${ }^{6}$, Kik Hao Samuel ${ }^{6}$ Hananta Linawati ${ }^{7}$

\footnotetext{
${ }^{1}$ Research unit Tropical Medicine (Tropmed), Faculty of Medicine, Universitas Gadjah Mada, Yogyakarta, Indonesia

${ }^{2}$ Department of Parasitology, Entomology and Tropical Disease, Faculty of Medicine, Universitas Gadjah Mada, Yogyakarta, Indonesia

${ }^{3}$ Department of Biochemistry, Faculty of Medicine, Universitas Gadjah Mada, Yogyakarta, Indonesia.

${ }^{4}$ Laboratory red blood cell and enzyme disorder, Eijkman Institute for Molecular Biology, Jakarta, Indonesia.

${ }^{5}$ Institute for Vector \& Reservoir Control Research \& Development (IVRCR\&D), National Institute of Health Research and Development, Ministry of Health, Salatiga, Cental Java, Indonesia.

${ }^{6}$ Health office of Timor Tengah Selatan District and Malaria Laboratory, Soe, Nusa Tenggara Timur Province, Indonesia.

${ }^{7}$ Department of Pharmacology and Pharmacy, Faculty of Medicine, University of Catholic Atmajaya, Jakarta, Indonesia
}

\begin{abstract}
Primaquine $(\mathrm{PQ})$ is a key drug in the malaria pre-elimination stage. However, $\mathrm{PQ}$ can trigger acute hemolysis for people with G6PD deficiency (G6PDd). In 2013, 15-25 million Indonesian people were infected with malaria, with 30,000-38,000 deaths each year mostly in eastern Indonesia with API $=15.6 \%$. Recently, the Ministry of Health of the Republic of Indonesia announced a plan to reach the pre-elimination stage based on WHO guidelines. This study assesses whether eastern Indonesia should proceed with the activities of malaria pre-elimination. A total 555 healthy people in five subdistricts in eastern Indonesia were selected by systematic random samping. All data were collected using a standard questionnaire, physical examination, and laboratory tests. PCR and DNA sequencing protocols followed respective manufacture's instructions. Statistical analysis by bivariate with $a=0.05$ and $95 \% \mathrm{CI}$ were performed using the SPSS software package. Based on the nested PCR, the result showed a malaria prevalence of $32.6 \%$ with being the dominant species $(52.5 \%)$. Malaria cases were found in all study sites and not using a bed net was the moost significant risk factors with $\operatorname{Exp~B=}$ 1.54 with $95 \% \mathrm{CI}=0.99-2.38$. G6PDd prevalence was $16.6 \%$, the highest G6PDd ever found in Indonesia with variant molecular dominant $10.883 \mathrm{~T}>\mathrm{C}$ and one sample with a heterozygous female. Malaria pre-elimination in eastern Indonesia should be delayed. High risk patients should be tested for enzyme G6PD activities before antimalarial administration.
\end{abstract}

Keywords: G6PDd, Vanua Lava, Pre-elimination malaria, Eastern Indonesia

\footnotetext{
*Corresponding author:

Jontari Hutagalung

Research unit Tropical Medicine (Tropmed), Faculty of Medicine, Universitas Gadjah Mada, Yogyakarta, Indonesia.
} 
Hutagalung et al.

\section{Introduction}

Glucose-6-phosphate dehydrogenase (G6PD) is an X-linked essential enzyme that protects cells from oxidative stress, particularly in red blood cells (RBC). G6PD deficiency (G6PDd), the most common known enzymopathy, is a hereditary genetic defect and it is one of the most prevalent polymorphisms in humans, especially in males (Kyoung et al., 2014). G6PD is an enzyme that plays an important role in protecting cells from oxidative damage by producing nicotinamide adenine dinucleotide phosphate $(\mathrm{NADPH})$ and reducing glutathione (GSH) in the erythrocyte. The G6PD gene is highly polymorphic with almost 400 reported variants, and is more commonly found in males than in females. This has led to the speculation that malaria has been the selection pressure that has favored the maintenance of this potentially deleterious trait. There is some evidence that hemizygous and heterozygous G6PDd may be protected against severe malaria. Most of individuals with G6PDd are normally asymptomatic, however, erythrocyte exposure to oxidative stress causes haemoglobin $(\mathrm{Hb})$ denaturation, and ultimately results in haemolysis. Haemolytic anemia in G6PDd can be triggered by a range of oxidative agents, such as infections and certain foods and drugs, including antimalarial 8-aminoquinolines like primaquine (Luzattoet al., 2001; Beutler and Vullamy, 2002; Clark et al., 2009).

Primaquine is the 8-aminoquinolines, a class of drugs discovered almost 80 years ago. Primaquine is administered to patients infected with (hypnozoites)to prevent relapse as wll as with to reduce gametocyte carriage to block transmission (Beutler et al., 1995). People with G6PD deficiency more susceptible to hemolysis when taking primaquine. Recently, the Ministry of Health $(\mathrm{MoH})$ of the Republic of Indonesia announced a plan to reach the pre-elimination stage by 2015-2020 and to be free of malaria transmission by 2030, and that it will use the World Health Organization (WHO) guidelines for pre-
I.J. Biotech, Vol. 20, No. 2

elimination activities. WHO criteria for preelimination are a reduction to zero incidence where the annual parasite incidence $(\mathrm{API})=$ $<1 / 1,000$ population, no local transmission, and with no risk factors for three consecutive years (Elyazar et al., 2011; Kemenkes RI, 2013; WHO, 2014).

In 2011-2014, there were 4.8 million cases of malaria reported in eastern Indonesia with $(62 \%)$ and (33\%) being the most common species (Elyazar et al., 2011; WHO, 2014). In this region, malaria is the primary cause of mortality with 23,483 deaths. South Central Timor (SCT) District, one of the highest malaria prevalence rates in eastern Indonesia with $\mathrm{API}=15.6 \%$ for more than 10 years following mother mortality rate (MMR) and infant mortality rate (IMR), twice higher than the national average (Kemenkes RI, 2013; Dinkes Prov. NTT, 2013; Dinkes TTS, 2014).

About 49 of 61 countries had failed to achieve malaria elimination in 2010. A review of resurgence in the Philippines and Thailand and two provinces in Indonesia, (Central Java and Kepulauan Seribu Island) that successfully pre-eliminated because of continued active control programs and passive case finding, and strong initiatives with neighboring countries, such as vector control, available operational drugs, and good surveillance systems (WHO, 2007; Feachem et al., 2010; Maharaj et al., 2012).

Malaria pre-elimination will be possible only with serious attempts to address asymptomatic and chronic infections by both and Currently in Indonesia, the available drugs that can completely clear a human of for radical cure and that can reduce the transmission of malaria parasites are those in primaquine, however, people with G6PDd risk having severe adverse reactions such as hemolysis if exposed to these drugs at certain doses (Syafrudin et al., 2009; Kathy et al., 2010). Since 1989, primaquine has been administered in the Indonesian regions without any G6PDd testing, and to date, no study has been undertaken to ascertain the prevalence of G6PDd in SCT District. This study reports on 
Hutagalung et al.

G6PDd prevalence and the variant molecular in a malaria endemic region regarding whether eastern Indonesia should proceed malaria preelimination activities.

\section{Materials and methods Ethics statements}

This study was approved by the ethics committee of the Faculty of Medicine, Universitas Gadjah Mada, Yogyakarta (reference No: KE/FK/85/EC). All participants signed a written consent form and gave their permission for the collection of blood samples.

\section{Samples}

A survey was conducted from August 2013 to September 2014. Sample size was calculated using a malaria prevalence of $15.6 \%$ in 2013 in South Central Timor District, eastern Indonesia (Lemenshow et al., 1997). Criteria for inclusion were $\geq 14$ years of age and hemoglobin $(\mathrm{Hb})$ level $=\geq$ $11 \mathrm{gr} / \mathrm{dL}$ by using HemoCue (HemoCue, 2013). Participants were interviewed face to face with a standard questionnaire, while household locations were obtained using the Garmin GPS 76, USA (Garmin International Inc., 2006). All participants underwent a physical examination by local health practitioners. During the interview, thick and thin blood smears (Giemsa 5\%) were made for malaria identification (Eijkman Institute for Molecular and Kemenkes RI, 2010).
I.J. Biotech, Vol. 20, No. 2

\section{Determination of G6PD activity}

Commercial quantitative G6PD enzyme test kits was used to screen for G6PDd population. G6PD enzyme activities were calculated at $340 \mathrm{~nm} / \mathrm{min}$ with a spectrophotometer at Biochemistry Laboratories, Faculty of Medicine, Universitas Gadjah Mada, Yogyakarta. All protocols to determine G6PD activities were according to manufacturer's instructions from the Randox G6PD test. The reliability of test results was monitored by calibration and including controls provided by the Randox G6PD test. Activity G6PD $\mathrm{mU} / \mathrm{gHb}=\mathrm{mU}$ eritrosit per $\mathrm{mL} \times 100 / \mathrm{Hb} \mathrm{g} / \mathrm{dL}$. The normal G6PD activities enzymes $=\geq 6.97-20.5 \mathrm{U} / \mathrm{gHb}$ (Randox Laboratories Limited, 2013).

\section{DNA extraction}

Whole blood samples were collected in an EDTA anticoagulant tube, specifically a $5 \mathrm{~mL}$ BD Vacutainer $5 \mathrm{~mL}$ (BD life science, 2014) and stored at $-20^{\circ} \mathrm{C}$ for molecular assessment. DNA was extracted from $200 \mu \mathrm{L}$ of whole blood using nucleon genomic DNA extraction kit (Promega Co., 2014).

\section{G6PDd genotype variant detection}

G6PD variants were detected using five sets of specific primers $(20-25 \mathrm{ng} / \mu \mathrm{L})$ from exon 5, 6, 9, 11, and 12 (Table 1). PCR amplification of G6PD gene was performed in $30 \mu \mathrm{L}$ total reaction, which consisted of $1 \mu \mathrm{L}$ each primer $(20 \mu \mathrm{M}), 2 \mu \mathrm{L}$ of DNA

Table 1. G6PD primers sequence and annealing temperature $\left({ }^{\circ} \mathrm{C}\right)$ for G6PD gene amplification.

\begin{tabular}{|c|c|c|c|}
\hline Exon & $\begin{array}{l}\text { PCR product } \\
\text { size }(\mathrm{bp})\end{array}$ & $\begin{array}{l}\text { Annealing } \\
\text { temp }\left({ }^{\circ} \mathrm{C}\right)\end{array}$ & Primers sequence \\
\hline 5 & 343 & 64,5 & $\begin{array}{l}\text { 5-ACA-CAC-GGA-CTC-AAA-GAG-AG-3 } \\
\text { 5-TGG-TGG-GAG-CAC-TGC-CTG-3 }\end{array}$ \\
\hline 6 & 320 & 65 & $\begin{array}{l}\text { 5-TGG-GAG-GGC-GTC-TGA-ATG-AT-3 } \\
\text { 5-TGG-TCC-TCA-CGG-AAC-AGG-GAA-G-3 }\end{array}$ \\
\hline 9 & 333 & 59 & $\begin{array}{l}\text { 5-TCC-CTG-CAC-CCC-AAC-TCA-AC-3 } \\
\text { 5-AGT-GCG-TGA-GTG-TCT-CAG-T-3 }\end{array}$ \\
\hline 11 & 157 & 65 & $\begin{array}{l}\text { 5-TGG-CAT-CAG-CAA-GAC-ACT-CTC-TC-3 } \\
\text { 5-CCC-CAT-AGC-CCA-CAG-GTA-TGC-AGG-3 }\end{array}$ \\
\hline 12 & 205 & 64 & $\begin{array}{l}\text { 5-TGT-GTG-CCA-CCG-GCC-TCC-CA-3 } \\
\text { 5-ATG-AGG-TAG-CTC-CAC-CCT-CA-3 }\end{array}$ \\
\hline
\end{tabular}


Table 2. List of the primers sequences and annealing temperature $\left({ }^{\circ} \mathrm{C}\right)$ for PCR-RFLP amplification.

\begin{tabular}{|c|c|c|c|c|}
\hline Variant G6PD & $\begin{array}{l}\text { Annealing } \\
\text { temp }\left({ }^{\circ} \mathrm{C}\right)\end{array}$ & Enzyme & Primers sequence & $\begin{array}{l}\text { PCR Product } \\
\text { size }\end{array}$ \\
\hline Viangchan /VC & 56 & Xba-1 & $\begin{array}{l}\text { 5-TGG-CTT-TCT-CTC-AGG-TCT-AG-3 } \\
\text { 5-GTC-GTC-CAG-GTA-CCC-TTT-GGG-G-3 }\end{array}$ & $126 \mathrm{bp}$ \\
\hline Chatham /CT & 61 & Bst-X-1 & $\begin{array}{l}\text { 5-CAA-GGA-GCC-CAT-TCT-CTC-CCT-T-3 } \\
\text { 5-TTC-TCC-ACA-TAG-AGG-AGG-ACG- } \\
\text { GCT-GCC-AAA-GT-3 }\end{array}$ & 208 bp \\
\hline $\begin{array}{l}\text { Vanua Lava / } \\
\text { VL }\end{array}$ & 65 & Eco-N-1 & $\begin{array}{l}\text { 5-CAG-CCT-GGG-GCA-GTG-TCT-GTG- } \\
\text { CT-3 } \\
\text { 5-GCG-GTT-GGC-CTG-TGA-CCC-CTG- } \\
\text { GTG-3 }\end{array}$ & $366 \mathrm{bp}$ \\
\hline
\end{tabular}

The enzyme from NEB =

Table 3. The primer sequence used for nested PCR and amplification of the species malariaidentification (Snounow 1993)

\begin{tabular}{lll}
\hline \multicolumn{1}{c}{ Primers } & \multicolumn{1}{c}{ Primers sequence } & $\begin{array}{l}\text { Product size (bp) } \\
\text { \& annealing }\left({ }^{\circ} \mathbf{C}\right)\end{array}$ \\
\hline $\begin{array}{l}\text { Ist round PCR } \\
\text { r-PLU-5 }\end{array}$ & $\begin{array}{l}\text { Plasmodium genus detection } \\
\text { 5-CTT -GTT-GTT-GCC-TTA-AAC-TTC }\end{array}$ & $1,2 \mathrm{~kb} / 58^{\circ}$ \\
r-PLU-6 & 5-TTA-AAA-TTG-TTG-CAG-TTA-AAA-CG & \\
$2^{\text {nd }}$ round PCR & Species identification & \\
r-FAL-1 & 5-TTA-AAC-TGG-TTT-GGG-AAA-ACC-AAA-TAT-ATT & $205 \mathrm{bp} / 58,5^{\circ}$ \\
r-FAL-2 & 5-ACA-CAA-TGA-ACT-CAA-TCA-TGA-CTA-CCC-GTC & \\
r-VIV-1 & 5-CGC-TTC-TAG-CTT-AAT-CCA-CAT-AAC-TGA-TAC & $120 \mathrm{bp} / 55^{\circ}$ \\
r-VIV-2 & 5-ACT-TCC-AAG-CCG-AAG-CAA-AGA-AAG-TCC-TTA & \\
r-OVA-1 & 5-ATC-TCT-TTT-GCT-ATT-TTT-TAG-TAT-TGG-AGA & $800 \mathrm{bp} / 54^{\circ}$ \\
r-OVA-2 & 5-GGA-AAA-GGA-CAC-ATT-AAT-TGT-ATC-CTA-GTG & \\
r-MAL-1 & 5-ATA-ACA-TAG-TTG-TAC-GTT-AAG-AAT-AAC-CGC & $144 \mathrm{bp} / 55^{\circ}$ \\
r-MAL-2 & 5-AAA-ATT-CCC-ATG-CAT-AAA-AAA-TTA-TAC-AAA & \\
\hline
\end{tabular}

template $(20-25 \mathrm{ng} / \mu \mathrm{L})$, green master mix PCR $15 \mu \mathrm{L}$ and $11 \mu \mathrm{L}$ distilled water. The PCR temperatures condition used were 30 cycles of initial denaturation at $95^{\circ} \mathrm{C}$ for 5 min, annealing for $30 \mathrm{sec}$ (table 1) and a final extension at $72^{\circ} \mathrm{C}$ for $5 \mathrm{~min}$ for 30 cycles (Nguyen et al., 2008). Positive and negative controls were used. The PCR products were resolved by electrophoresis on $1.5 \%$ agarose gel, containing $5 \mu$ L ethidium bromide (EtBr) (Promega, USA). DNA ladder was used (Vivantis Tech, Malaysia). G6PD variants were detected by sequencing (ABI Prism 310 genetic sequencer, Macrogen 2014). G6PDd were classified according to WHO G6PDd with five level criteria (Marina et al., 1998).

We also re-confirmed the G6PD mutations that were found by PCR-RFLP using three variants most common in Asia (Nguyen et al., 2008) (Table 2). PCR-RFLP amplification was performed in $25 \mu \mathrm{L}$ total reaction, with all protocols PCR-RFLP following the guidelines of KAPA HiFi, Boston, USA, cat. No. KK-2101 (Kappa Biosystems, 2013; Nicole 2014). The G6PD variants were Vanua Lava $10.884 \mathrm{~T}>\mathrm{C}$ with enzyme restriction, Viangchan Jammu 13.031 G>A with enzyme restriction Xba1, and Chatham $13.163 \mathrm{G}>\mathrm{A}$ with enzyme restriction BstX-1 (New England BioLabs, 2013).

\section{Plasmodium identification}

Identification of species used double assignment, microscopic by Giemsa $5 \%$ and nested PCR with ten sets of primers. Nested-1 
Hutagalung et al.

using primers r-PLU-5 and r-PLU-6 and nested-2 using primers are shown in Table 3.

Total nested PCR reaction $25 \mu \mathrm{L}, \mathrm{PCR}$ using protocols in accordance with Promega, Madison, USA (Cat. No. M-7122) with PCR condition followed from Snounow (1993). A positive control using known samples of and nuclease-free water is used as a negative control. $1.5 \%$ agarose gel from Bioron, Germany (Cat. No. 604001), containing $5 \mu \mathrm{l} / \mathrm{mL}$ ethidium bromide from Promega, Madison, USA (Cat. No. H-5041) was used for electrophoresis. Bands were visualized by ultra violet illumination with DNA ladder from Vivantis, Selangor, Malaysia, Cat. No. NL-1407.

\section{Statistical analysis}

This study was evaluated by univariate, bivariate (chi-square), and multivariate statistical analysis test with $a=0.05$ and 95\% confident interval (CI) using the SPSS 16.0 software package. G6PDd subjects were classified as normal and deficient of G6PD enzymatic activities on the basis of the Randox G6PD test (Ranjit, 1999; Martin, 2000).

\section{Results and Discussion}

Demography malaria and G6PD prevalence

A total 555 of 558 individuals who were screened in five subdistricts (Oinlasi, Oe'ekam, Panite, Batu Putih, and Oenino), systematically selected, and completed the questionnaire also provided blood samples for analyses of G6PD status and malaria (Figure 1).

The primary objective of this study was to describe the prevalence of G6PDd in eastern Indonesia. G6PDd prevalence was $16.4 \%(91 / 555)$ and predominately female at $56.5 \%$ (52/92). Amongst age groups, 41-51 years old had the highest prevalence with $30.4 \%$ (28/92). The current study was higher compared with previous reports from other parts of Indonesia, such as Sumba District (5.1\%) and Flores District $(7.5 \%)$, and Malaysia $(3.4 \%)$, Vanuatu $(6.9 \%)$, Korea $(0.5 \%)$, and
I.J. Biotech, Vol. 20, No. 2

Vietnam (8.7\%). Samples were selected from healthy individuals in the general population from particular malaria endemic areas, so it is surprising that G6PDd frequencies are divergent from previous reports. However, there are probably very few regions studied with regards to G6PD testing specifically in Indonesia (Ganczakowski et al., 1995; Ainoon 2002; Nguyen et al., 2009; Matsuoka et al., 2013; Satyagraha et al., 2015).

G6PDd prevalence was higher in three malaria endemic regions, Oinlasi Subdistrict (42.8\%), Panite Subdistrict (20.8\%) and Oe'ekam subistrict $16.5 \%$ where malaria status level high cases incidence and middle cases incidence. A high G6PDd was found in South Central Timor District, justified malaria transmission were unstable transmission area and high potential occurs malaria outbreak. G6PDd testing needs to be undertaken, because currently only primaquinine remains as the drug of choice for radical cure for hypnozoites and controlling malaria transmission, and the risk associated with its use must be minimized during pre-elimination (Nick et al., 2011; Goo et al., 2014). All patients with positive malaria should be tested for G6PD enzyme activities and adequately informed before primaquine is administered. In an individual with G6PDd, primaquine should be prescribed in lower doses. WHO suggested using an intermittent primaquine regimen of $0.75 \mathrm{mg}$ base $/ \mathrm{kg}$ once a week for eight weeks to help the malaria pre-elimination program(Kemenkes RI, 2010; Gonzalo et al., 2013).

Because the majority of respondents in this study were Timorese, it was also the dominant ethnicity with G6PDd (95.6\%). Based on the results of the nested PCR, 22 of the 91 G6PDd cases (24\%) were infected with malaria with being the most dominant species.

Another important finding in this study was the prevalence of anemia ( $\mathrm{Hb}=\leq 11 \mathrm{~g} /$ $\mathrm{dL}$ ) in people with G6PDd (83 cases or $91 \%$ ) and most respondents with G6PDd (98\%) had a history of malaria infection (Table 5). Of the risk factors, five variables were 


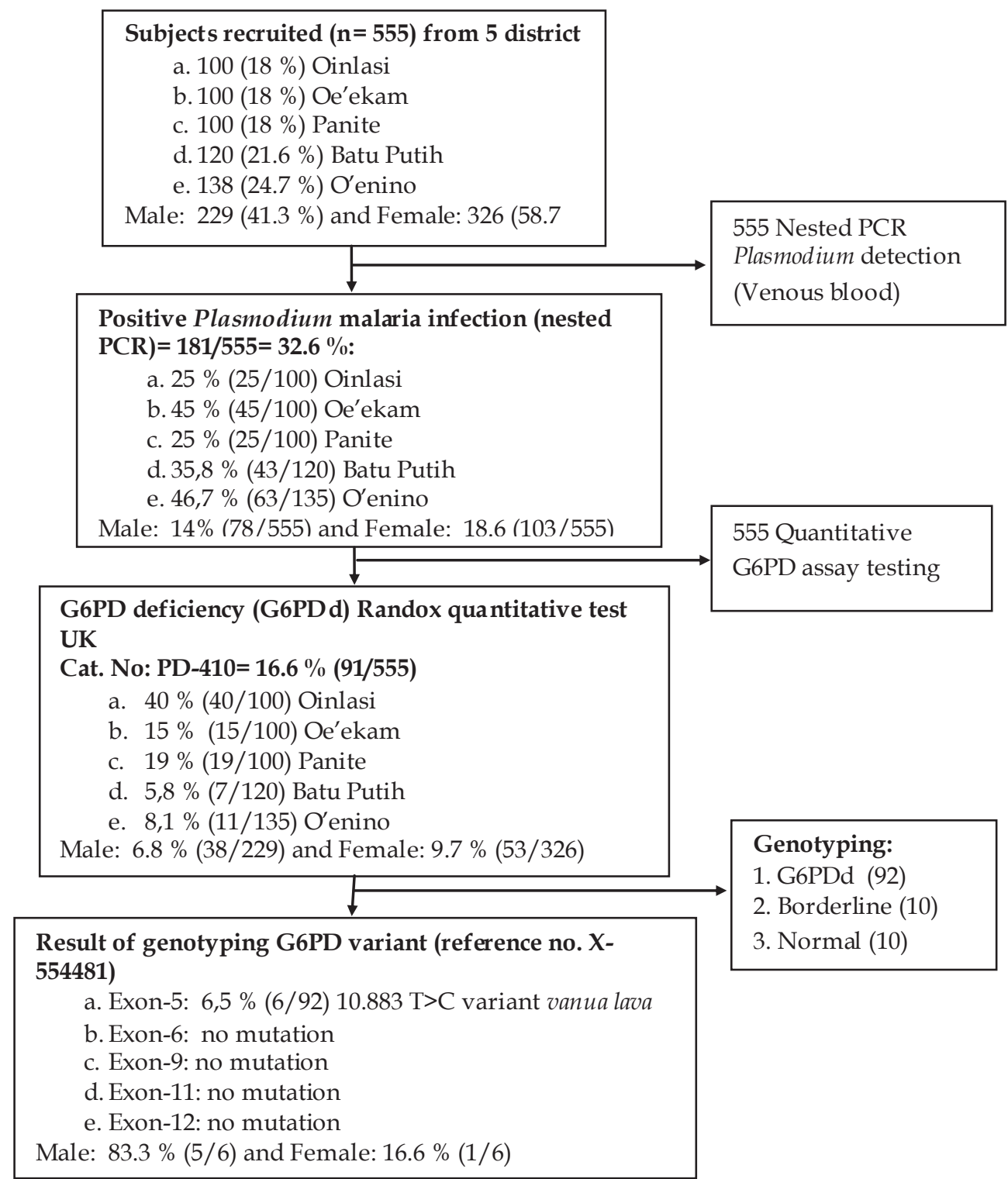

Figure 1. Schematic work flow of this study on malaria prevalence, enzyme activity, and G6PD variants in eastern Indonesia.

significant: decreased $\mathrm{Hb}$ level $\mathrm{P}=<0.05$ and $\mathrm{OR}=1.26$, abortion history $\mathrm{P}=<0.05$ and $\mathrm{OR}$ $=1.04$, antimalarial primaquine consuming $\mathrm{P}$ $=<0.05$ and $\mathrm{OR}=1.14$, favism diet $\mathrm{P}=<0.05$ and $\mathrm{OR}=1.95$ and malaria infection history $\mathrm{P}=<0.05$ and $\mathrm{OR}=1.07$. G6PDd correlated reasonably well with decreased hemoglobin levels, with average G6PDd respondents' mean $\mathrm{Hb}(11.7 \mathrm{~g} / \mathrm{dL})$ lower than the normal group (13.3 g/dL). G6PD activity significant with decreasing hemoglobin levels, in other words, anemia appeared to directly impact
G6PD activity. The explanations for anemia are reticulocytemia among the anemia and natural decay as red blood cells age. These results are consistent with a study in the National Medical Center and Howard University, Washington DC, USA by Smith et al. (2009), which showed that G6PDd had a significant effect on $\mathrm{Hb}$ concentration; however, the G6PD activities level was no different in G6PD normal subjects versus those who were G6PD deficient (Jansen et al., 1985; Lorenz et al., 2013; Mehdi et al., 2010). 


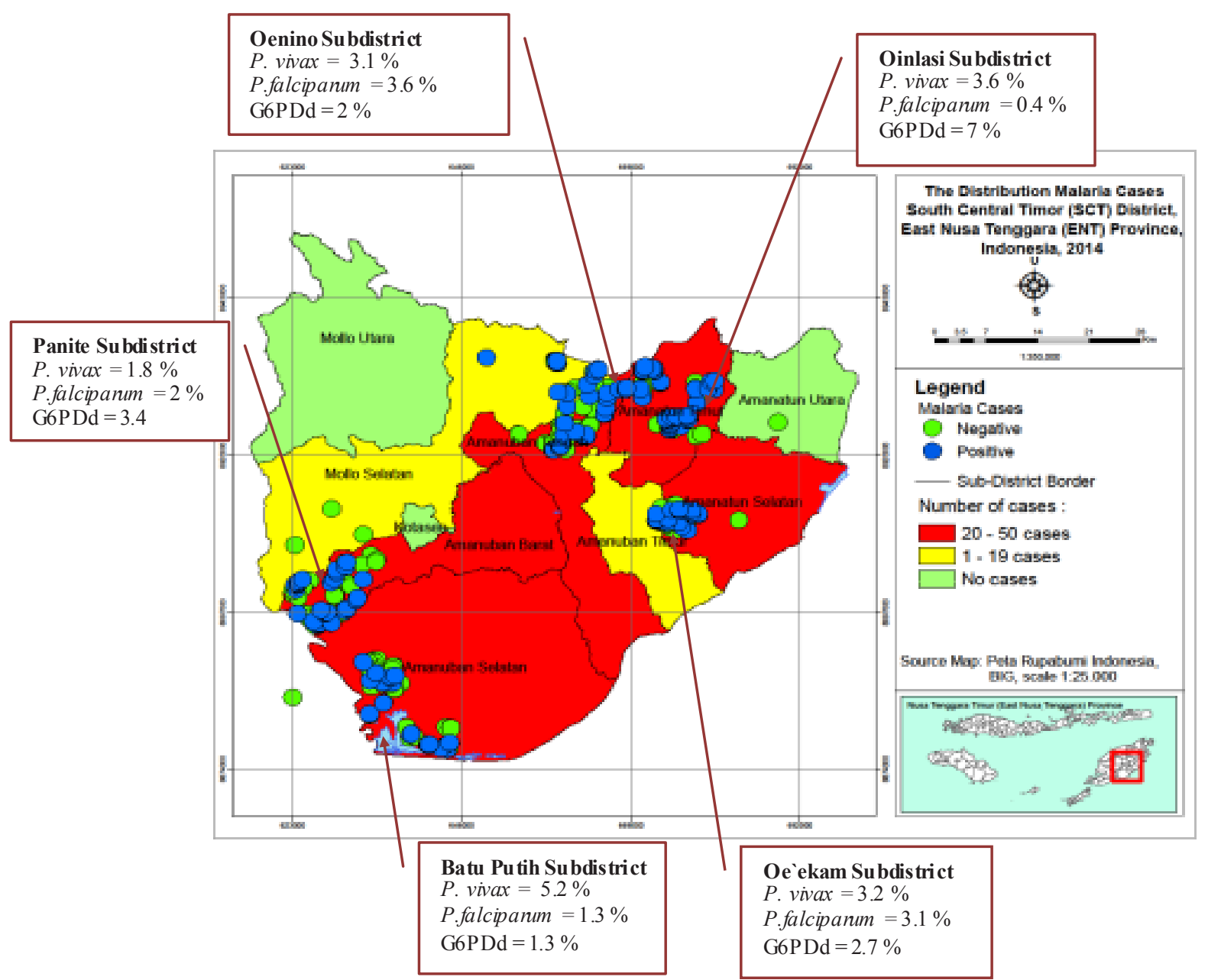

Figure 2. The distribution of the G6PDd and malaria cases in Timor Tengah Selatan district, Nusa Tenggara Timur Province, Indonesia

The prevalence of malaria by nested PCR was higher than that based on microscopic results; $32.6 \%(181 / 555)$ and $1.6 \%(9 / 555)$, respectively, with as the most dominant. There were more females $(57 \%)$ than males $(43 \%)$ infected by malaria and the age group with highest malaria infection was $\geq 51$ years $(35.9 \%)$. Overall, malaria cases were found in all districts and even in districts with a low cases incidence (LCI).

Even the prevalence of malaria was high and no variables significant $(p=>005)$ to the malaria risk factors, but the $\mathrm{OR}=>1$, in this study most of eastern Indonesia is living with endemic However, blood surveys for this parasite are unlikely to detect the dormant liver stage of infection, so the prospects for pre-elimination would be improve by combining G6PDd distribution, antimalarial therapy practices, and manageability of malaria infection risk (Carlos et al., 2008; Hay et al., 2007; Howes et al., 2012; ).

\section{G6PD Gene Genotype}

We also screened the nucleotide substitution position which absent from data based on G6PDd variant (WHO and Minucci et al.,2012). Sequence analysis presents a summary of molecular across five exons of the G6PD gene $(5,6,9,11$, and 12$)$. Genotype was available for $60.9 \%$ (56/92). However, only $8.9 \%(6 / 56)$ identified with the variant $(10.884 \mathrm{~T}>\mathrm{C})$ with one sample being a heterozygous female (Table 8 ). 
Table 4. Distribution of G6PDd (quantitative test), South Central Timor District, Eastern Indonesia.

\begin{tabular}{|c|c|c|c|}
\hline \multirow{2}{*}{ Variables } & \multicolumn{2}{|c|}{ G6PD-d result (quantitative) } & \multirow{2}{*}{ - Total $(\%)$} \\
\hline & Deficiency (\%) & Non deficiency $(\%)$ & \\
\hline \multicolumn{4}{|l|}{ Sex: } \\
\hline Male & $40(7.2)$ & $189(34.1)$ & $229(41.3)$ \\
\hline Female & $52(9.2)$ & $275(49.5)$ & $326(58.7)$ \\
\hline \multicolumn{4}{|l|}{ Age groups (years): } \\
\hline$<15$ & $0(0)$ & $11(2.0)$ & $11(2.0)$ \\
\hline $16-20$ & $2(0.4)$ & $12(2.2)$ & $14(2.5)$ \\
\hline $21-30$ & $18(3.2)$ & 63 (11.4) & $81(14.6)$ \\
\hline $31-40$ & $17(3.1)$ & $136(24.5)$ & $153(27.6)$ \\
\hline $41-50$ & $28(5.0)$ & 105 (18.9) & $133(24.0)$ \\
\hline$>51$ & $26(4.7)$ & $137(24.7)$ & $163(29.4)$ \\
\hline \multicolumn{4}{|l|}{ Subdistrict: } \\
\hline Oinlasi & $39(7.0)$ & $61(11.0)$ & $100(18.0)$ \\
\hline Oe'ekam & $15(2.7)$ & 85 (15.3) & $100(18.0)$ \\
\hline Panite & $19(3.4)$ & 81 (14.6) & $100(18.0)$ \\
\hline Batu Putih & $7(1.3)$ & $113(20.4)$ & $120(21.6)$ \\
\hline Oenino & $11(2.0)$ & $124(22.3)$ & $135(24.3)$ \\
\hline \multicolumn{4}{|l|}{ Ethnicity: } \\
\hline Belunese & $1(0.2)$ & $0(0)$ & $1(0.2)$ \\
\hline Sumbanese & $1(0.2)$ & $2(0.4)$ & $3(0.5)$ \\
\hline Rotenese & $1(0.2)$ & $25(4.5)$ & $26(4.7)$ \\
\hline Sabunese & $1(0.2)$ & $6(1.1)$ & $7(1.3)$ \\
\hline Timorese & $87(15.7)$ & 425 (76.6) & $512(92.3)$ \\
\hline Others* & $0(0)^{*}$ & $6(1.0)^{*}$ & $6(1.0)^{*}$ \\
\hline \multicolumn{4}{|l|}{ Nested PCR result: } \\
\hline . & $5(0.9)$ & $52(9.4)$ & $57(10.3)$ \\
\hline . & $11(2.0)$ & 84 (15.1) & 95 (17.1) \\
\hline \multirow{2}{*}{ and } & $6(1.1)$ & $23(4.1)$ & $29(5.2)$ \\
\hline & $0(0)$ & $0(0)$ & $0(0)$ \\
\hline Negative & $69(12.4)$ & $305(55.0)$ & $374(67.4)$ \\
\hline \multicolumn{4}{|l|}{ Haemoglobin level: } \\
\hline Normal (11 gr/dl) & $8(1.4)$ & $197(35.5)$ & $205(36.9)$ \\
\hline Anaemia (<11 gr/dl) & $83(15.0)$ & $267(48.1)$ & $350(63.1)$ \\
\hline \multicolumn{4}{|c|}{ Historyof infected malaria: } \\
\hline Yes & $2(0.4)$ & $37(6.7)$ & $39(7.0)$ \\
\hline No & $89(16.0)$ & $427(76.9)$ & $516(93.0)$ \\
\hline Total & $91(16.4)$ & $464(83.6)$ & $555(100)$ \\
\hline
\end{tabular}

An expected result we found was female heterozygous, 48 years old with lower range of enzymes G6PD activity <3.9 $\mathrm{U} / \mathrm{grHb}$, and negative result malaria. This displayed a wide range of G6PD variant in eastern Indonesia. Heterozygosity imposes greater complexity to the consideration of primaquinine therapy. From the postulated evolution of G6PDd, it is possible that the frequency of malaria is lower in patients with G6PDd (White et al., 2012). We would conclude that heterozygous G6PDd females could perhaps prove vulnerable and very sensitive to antimalarial primaquine therapy in terms of risk of hemolytic anemia. Indeed screening for G6PDd prior to primaquinine therapy would likely be required to protect patients diagnosed with a infection (Marla et al., 2009).

\section{Malaria pre-elimination program in eastern Indonesia}

The malaria pre-elimination activities in eastern Indonesia should be delayed because 
Table 5. Bivariate analysis on G6PDd risk factors ( $a=0.05$ with $95 \% \mathrm{CI})$.

\begin{tabular}{|c|c|c|c|c|}
\hline \multirow{2}{*}{ Variables } & \multicolumn{2}{|c|}{ G6PDd result } & \multirow{2}{*}{$\begin{array}{c}\text { OR/ } \\
\text { P-value }\end{array}$} & \multirow{2}{*}{$\begin{array}{c}95 \% \text { CI } \\
\text { Lower-Upper }\end{array}$} \\
\hline & $(+)$ deficiency $(\%)$ & Normal (\%) & & \\
\hline $\begin{array}{l}\text { Malaria endemic } \\
\text { malaria: } \\
\leq 5 \text { years } \\
\geq 6 \text { years }\end{array}$ & $\begin{array}{l}12(2.2) \\
79(14.2)\end{array}$ & $\begin{array}{l}60(10.8) \\
404(72.8)\end{array}$ & $1.04(0.53)$ & $0.89-1.12$ \\
\hline $\begin{array}{c}\text { Haemoglobin }(\mathrm{Hb}) \text { level: } \\
\text { Anaemia }(<11 \mathrm{gr} / \mathrm{dl}) \\
\text { Normal }( \pm 11 \mathrm{gr} / \mathrm{dl})\end{array}$ & $\begin{array}{l}83(15) \\
8(1.4)\end{array}$ & $\begin{array}{l}267(48.1) \\
197(35.5)\end{array}$ & $1.26(0.00)^{*}$ & $1.18-1.34^{*}$ \\
\hline $\begin{array}{l}\text { Abortion history: } \\
\text { Yes (+) } \\
\text { No (-) }\end{array}$ & $\begin{array}{l}4(0.7) \\
87(15.7)\end{array}$ & $\begin{array}{l}54(9.7) \\
410(73.9)\end{array}$ & $1.04(0.02)^{*}$ & $1.04-1.22^{*}$ \\
\hline $\begin{array}{l}\text { History antimalarial: } \\
\text { Yes }(+) \\
\text { No }(-)\end{array}$ & $\begin{array}{l}2(0.4) \\
89(16)\end{array}$ & $\begin{array}{l}37(6.7) \\
427(76.9)\end{array}$ & $1.14(0.03)^{*}$ & $1.05-1.24^{*}$ \\
\hline $\begin{array}{l}\text { Favism diet: } \\
\text { Yes }(+) \\
\text { No }(-)\end{array}$ & $\begin{array}{l}19(3.4) \\
72(13.0)\end{array}$ & $\begin{array}{l}47(8.5) \\
417(75.1)\end{array}$ & $1.95(0.05)^{*}$ & $1.26-3.02 *$ \\
\hline $\begin{array}{l}\text { Others Infection history: } \\
\text { Yes (+) } \\
\text { No }(-)\end{array}$ & $\begin{array}{l}39(7.0) \\
52(9.4)\end{array}$ & $\begin{array}{l}183(33) \\
280(50.5)\end{array}$ & $0.97(0.31)$ & $0.90-1.05$ \\
\hline $\begin{array}{l}\text { Malaria infected: } \\
\text { Positive }(+) \\
\text { Negative }(-)\end{array}$ & $\begin{array}{l}22(4.0) \\
69(12.4)\end{array}$ & $\begin{array}{l}159(28.6) \\
305(55)\end{array}$ & $1.07(0.03)^{*}$ & $1.00-1.15^{*}$ \\
\hline
\end{tabular}

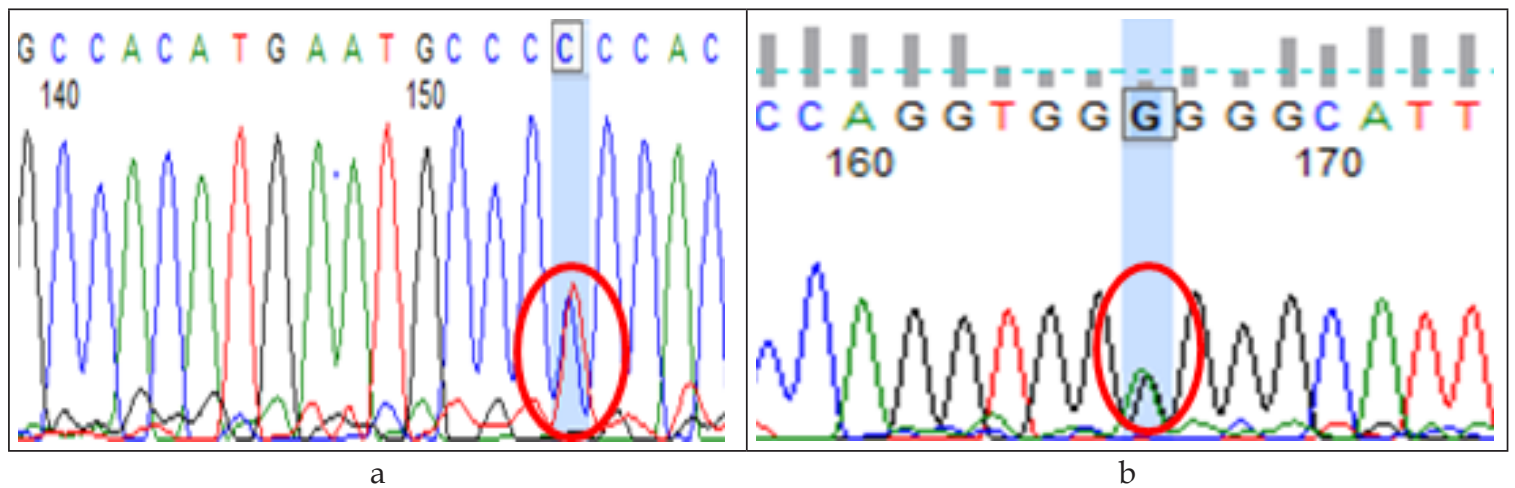

Figure 3. DNA sequencing result of heterozygous female G6PDd, female (SCT-233), 48 years old, negative malaria, (a) forward primer, and (b) reverse primer. Nucleotide subtitution $10.884 \mathrm{C}>\mathrm{T}$ at codon 128 exon-5.

they do not meet the WHO guidelines of an API of $<1 / 1,000$ population (Rajendra et al., 2012). The prevalence of malaria based on this study by nested PCR $(32.6 \%)$ was still high compared with the microscopic test result $(1.6 \%)$, with dominating. In order to achieve pre-elimination according to $\mathrm{WHO}$, API must reach $<1$ case per 1000 people, unfortunately this assessment's results were not consistent with the national plans for pre-elimination by 2015-2020 (Kemenkes RI, 2010). Malaria is a major public health burden in eastern Indonesia affecting vast regions. Based on a health office report from 2005 to 2010, there were outbreaks in 19 provinces, covering 65 districts with 58,152 cases and 536 reported deaths CFR $=>0.9 \%$ (Elyazar et al., 2011). 
Table 6. The distribution of malaria cases by nested PCR result.

\begin{tabular}{|c|c|c|c|c|c|}
\hline \multirow[b]{2}{*}{ Variables } & \multicolumn{4}{|c|}{ Malaria infections based on by nested PCR } & \multirow[b]{2}{*}{ Total $(\%)$} \\
\hline & P. falciparum (\%) & P. $\operatorname{vivax}(\%)$ & $\begin{array}{c}\text { P. falciparum } \\
\text { and P.vivax }(\%)\end{array}$ & $\begin{array}{c}\text { Total infected } \\
(\%)\end{array}$ & \\
\hline \multicolumn{6}{|l|}{ Sex: } \\
\hline Male & $23(29.5)$ & $43(55.1)$ & $12(15.4)$ & $78(34.1)$ & $229(41.3)$ \\
\hline Female & $34(33)$ & $51(49.5)$ & $18(17.5)^{-}$ & $103(31.6)$ & $326(58.7)$ \\
\hline \multicolumn{6}{|l|}{ Age groups (years): } \\
\hline$\leq 15$ & $1(33)$ & $2(67)$ & $0(0.0)$ & $3(27.3)$ & $11(2.0)$ \\
\hline $16-20$ & $3(75)$ & $0(0.0)$ & $1(25)$ & $4(28.6)$ & $14(2.5)$ \\
\hline $21-30$ & $6(33.3)$ & $7(33.9)$ & $5(27.8)$ & $18(22.2)$ & $81(14.6)$ \\
\hline $31-40$ & $15(31.9)$ & $25(53.2)$ & 7 (14.9) & $47(30.7)$ & $153(27.6)$ \\
\hline $41-50$ & $8(18.2)$ & $30(68.2)$ & $6(13.6)$ & $44(33.1)$ & $133(24.0)$ \\
\hline$\geq 51$ & $24(36.9)$ & $30(46.1)$ & $11(16.9)$ & 65 (39.9) & $163(29.4)$ \\
\hline \multicolumn{6}{|l|}{ Subdistrict: } \\
\hline Oinlasi (HCI) & $2(8)$ & $20(80)$ & $3(12)$ & $25(25)$ & $100(18.0)$ \\
\hline Oe'ekam (HCI) & $17(37.8)$ & $18(40)$ & $10(22.2)$ & $45(45)$ & $100(18.0)$ \\
\hline Panite (MCI) & $11(44)$ & $10(40)$ & $4(16)$ & $25(25)$ & $100(18.0)$ \\
\hline Batu Putih (LCI) & $7(16.3)$ & $29(67.4)$ & 7 (16.3) & $43(35.8)$ & $120(21.6)$ \\
\hline Oenino (LCI) & $20(31.7)$ & 17 (26.9) & $6(9.5)$ & $63(46.7)$ & $135(24.3)$ \\
\hline \multicolumn{6}{|l|}{ Ethnic: } \\
\hline Timorese & $54(32.5)$ & $84(50.6)$ & $28(16.8)$ & $166(32.4)$ & $512(92.3)$ \\
\hline Sabunese & $1(33.3)$ & $2(66.7)$ & $0(0.0)$ & $3(42.8)$ & $7(1.3)$ \\
\hline Rote & $2(18.2)$ & $8(72.7)$ & $1(9.1)$ & $11(42.3)$ & $26(4.7)$ \\
\hline Bugis & $0(0.0)$ & $0(0.0)$ & $0(0.0)$ & $0(0)$ & $1(0.2)$ \\
\hline Sumbanese & $0(0.0)$ & $0(0.0)$ & $0(0.0)$ & $0(0)$ & $3(0.5)$ \\
\hline Others* & $0(0.0)^{*}$ & $0(0.0)^{*}$ & $1(100)^{*}$ & 1 (16.7) & $6(1.0)^{*}$ \\
\hline \multicolumn{6}{|l|}{ Length of stay (years): } \\
\hline$\leq 5$ & $50(31.4)$ & $82(51.6)$ & $27(16.9)$ & 159 (32.9) & $483(87.0)$ \\
\hline$\geq 6$ & $7(31.8)$ & $12(54.5)$ & $3(13.6)$ & $22(30.5)$ & $72(13.0)$ \\
\hline \multicolumn{6}{|l|}{ Haemoglobin $(\mathrm{Hb})$ : } \\
\hline 1. Anemia $(\leq 10 \mathrm{~g} / \mathrm{dl})$ & $34(30.4)$ & $58(51.8)$ & $20(8.4)$ & $112(32)$ & $350(36.9)$ \\
\hline $\begin{array}{l}\text { 2. No anemia (>10 g/ } \\
\text { dl) }\end{array}$ & $23(33.3)$ & $36(52.2)$ & $10(14.5)$ & $69(33.6)$ & $205(36.9)$ \\
\hline \multicolumn{6}{|l|}{ Antimalarial drug } \\
\hline history: & $5(38.5)$ & $6(46.2)$ & $2(15.4)$ & $13(33.3)$ & $39(7.0)$ \\
\hline 1. Yes & $52(30.9)$ & $88(52.4)$ & $28(16.7)$ & $168(32.6)$ & $516(93.0)$ \\
\hline 2. No & & & & & \\
\hline
\end{tabular}

* Others=Sundanese, Sundanese, Batak and Chinese $/{ }^{*}$ Malariae and ovale negative for all survey participant/HCI= high cases incidence API $>5 \%$ o $/ \mathrm{MCI}=$ middle cases incidence $=$ API 2-4\% $/ \mathrm{LCI}=$ low cases incidence $=\mathrm{API}<1 \%$.

To address malaria pre-elimination many interventions have been carried out. Residual spraying with insecticides (initially DDT), rapid diagnostic tests, artemisininbased combination therapy (ACT), and surveillance have been introduced since 2005 (Noor et al., 2010). In successful cases in Central Java Province, Jembrana (Bali Island), and Sabang District (Aceh Province) intervention focused solely on malaria preelimination with seven recommended steps:
(1) producing a map of endemicity and foci of malaria, (2) assessing the feasibility of collaboration between communities and government, (3) developing a strategic plan for malaria control, (4) support from the district health office and legislative council, (5) developing an integrated working plan, (6) implementing the working plan, and (7) monitoring and evaluating the strategy and the progress made (Omumbo et al., 2005; Herdiana et al., 2013). 
Table 7. Bivariate analysis on malaria risk factors in eastern Indonesia.

\begin{tabular}{|c|c|c|c|c|}
\hline \multirow{2}{*}{ Variables } & \multicolumn{2}{|c|}{$\begin{array}{c}\text { Nested PCR result } \\
\text { (Plasmodium identification) }\end{array}$} & \multirow{2}{*}{$\begin{array}{l}\text { Odds Ratios } \\
\text { (OR) }\end{array}$} & \multirow{2}{*}{$\begin{array}{c}95 \% \text { CI } \\
\text { Lower-Upper }\end{array}$} \\
\hline & Positive (\%) & Negative (-) & & \\
\hline \multicolumn{5}{|l|}{ Sex: } \\
\hline Male & $78(14.1)$ & $151(27.2)$ & 1.07 & $0.84-1.37$ \\
\hline Female & $103(18.6)$ & $223(40.2)$ & & \\
\hline \multicolumn{5}{|l|}{ Visited others district: } \\
\hline Yes & $76(13.7)$ & $154(27.7)$ & 1.02 & $0.80-1.30$ \\
\hline No & $105(18.9)$ & $220(39.6)$ & & \\
\hline \multicolumn{5}{|l|}{ Using bed nets: } \\
\hline Yes & $146(26.3)$ & $274(49.4)$ & 1,52 & $0.98-2.35$ \\
\hline No & $35(6.3)$ & $100(18)$ & & \\
\hline \multicolumn{5}{|c|}{ Sleeping out of the house at night (field): } \\
\hline Yes & $46(8.3)$ & $94(17)$ & 1.01 & $0.77-1.33$ \\
\hline No & $134(24.2)$ & $280(50.5)$ & & \\
\hline \multicolumn{5}{|l|}{ Screen ventilation used: } \\
\hline Yes & $3(0.5)$ & $2(0.4)$ & 1.85 & $0.89-3.83$ \\
\hline No & $177(32.0)$ & $371(67.1)$ & & \\
\hline \multicolumn{5}{|l|}{ Living near cattle shed: } \\
\hline Yes & $124(22.3)$ & $251(45.2)$ & 1.04 & $0.80-1.35$ \\
\hline No & $57(10.3)$ & $123(22.2)$ & & \\
\hline \multicolumn{5}{|c|}{ Mosquitos breeding places near home: } \\
\hline Yes & $144(25.9)$ & $306(55.1)$ & 1.05 & $0.90-1.22$ \\
\hline No & $37(6.7)$ & $68(12.3)$ & & \\
\hline
\end{tabular}

* Significant variable $(\mathrm{p}=<0.05)$

Table 8. The sequencing alignment result on G6PD gene mutation (accession reference no. X-554481).

\begin{tabular}{cllccc}
\hline Exon & $\begin{array}{c}\text { No. sample } \\
\text { mutation (\%) }\end{array}$ & $\begin{array}{c}\text { Nucleotide (nt) position } \\
\text { substitution }\end{array}$ & $\begin{array}{c}\text { Codon/ } \\
\text { Amino acid } \\
\text { substitution }\end{array}$ & $\begin{array}{c}\text { Class } \\
\text { G6PDd } \\
\text { WHO }\end{array}$ & $\begin{array}{c}\text { Variant } \\
\text { G6PDd }\end{array}$ \\
\hline 5 & $6(6.4)$ & $10.884 \mathrm{~T}>\mathrm{C}$ & $128 \mathrm{Leu}>$ Pro & II & No mutation \\
6 & $0(0)$ & - & - & - & - No mutation \\
9 & $0(0)$ & - & - & - & No mutation \\
11 & $0(0)$ & - & - & - & No mutation \\
\hline
\end{tabular}

${ }^{*} \mathrm{C}=$ Cytosin/T=Timin/Leu=Leusina/Pro=Prolina

This study suggests that more active and passive case finding coupled with periodic Mass Blood Surveys (MBS), case management with effective drugs, vector control, and good surveillance is needed. The conception is very different and rather more complex in the remaining eastern Indonesia and the absolute feasibility of this goal would need to be further assessed with additional work. The situation is entirely different in other province in Indonesia. Reducing high risk because a lot of remote areas, limited development of healthcare facilities, systems delivering prompt diagnosis, effective treatment including services are the challenge we should manage to achieve malaria preelimination in eastern Indonesia (David et al., 2013).

For the population at risk estimates will allow malaria control managers for vector control interventions, help forecast the number of Long-Lasting Insecticide Treated Nets (LLINs) that need to be procured and distributed. The cost estimates of scaling 
Hutagalung et al.

up LLIN coverage can also be calculated; however, the distribution of the malaria transmitted and the distribution G6PDd need evaluation before any intervention is scaled up (Carlos et al., 2008). The mapping analysis showed that transmission is not homogeneous. Malaria risk is displayed in a whole area of study site. This map provide the base for designing a surveillance strategy and will be fully implemented by targeted inland hotspot for prevent an outbreak. The endemicity maps were used to estimate real incidence malaria and G6PD in areas for pre-elimination. The new methods with serologic assignment is needed to support the pre-elimination program (Howes et al., 2012; Supargiyono et al., 2013).

There are limitations in this study. When selected participants are from a healthy population we cannot describe the real signs and symptoms due to the effect of G6PDd and malaria. Therefore, this study requires further exploration in prospective studies.

\section{Conclusion and recommendation}

In summary, our survey of G6PD in eastern Indonesia variant $(10.884 \mathrm{~T}>\mathrm{C})$ was relatively common within Asia and eastern Indonesia. Primaquine treatment has the potential to induce oxidative stress, and has a significant risk of causing decreased $\mathrm{Hb}$ or adverse hemolysis. Therefore, a G6PD assessment should be conducted before antimalarial drug administration. The malaria pre-elimination program in eastern Indonesia should be delayed. Instead, routine treatment to stop silent transmission, outbreak control, and further tests on G6PDd is required before the administration of primaquinine, and more sensitive laboratory support is needed before the pre-elimination program is carried out.

\section{Acknowledgements}

This study was funded by the Asia Pacific Malaria Elimination Network (APMEN), project number 103-02 as part
I.J. Biotech, Vol. 20, No. 2

of the APMEN Country Partner Technical Development Program, Round X. Major funding for APMEN is provided by Australian Government's Department of Foreign Affairs and Trade, alongside funds received from the Bill and Melinda Gates Foundation. Our special thanks go to the all the respondents of South Central Timor (SCT) District, East Nusa Tenggara (ENT) Province, local staff in the SCT District Health Office and local laboratories, ENT Province, Faculty of Medicine UGM (Ph.D program), Institute for Vector \& Reservoir Control Research \& Development (IVRCR\&D), National Institute of Health Research and Development, $\mathrm{MoH}$ Indonesia, Salatiga, Cental Java (Biology Molecular Laboratories), and all staff of the Eijkman Institute for Molecular Biology (Malaria I, II and RBC \& Enzyme disorder Laboratory). Special thanks go to Prof. Mo Salman (College of Veterinary Medicine and Biomedical Science, Colorado State University, Fort Collins, USA), Dr. Alden Henderson (Centers for Disease Control and Prevention, USA), Dr. Ari Winasti Satyagraha, and Dr. Rintis Novijanti (Eijkman Institute for Molecular Biology, Jakarta) for editing this manuscript, and lastly, we wish to thank Mr. Alex H. Rambadeta (a freelance editor) for his assistance in advising on the grammatical and spelling accuracy of the text where appropriate.

\section{References}

Ainoon. I, Y., H. Yu, A. L. Amir Muhriz, N. Y. Boo, S. K. Cheong and N. H. Hamidah., 2002. Glucose-6-Phosphate Dehydrogenase (G6PD) variants in Malaysian Malays. Human Mutation in Brief 574: 2-7.

BD life sciences, (2014) BD life sciencespreanalytical systems, Product catalog. 1-Becton Drive Franklin Lakes. NJ 07417. USA: 1-4.

Beutler E., Westwood B, Melemed A, Patricia Dal Borgo, Margolis D., 1995. Three new exon 10 glucose-6-phosphate dehydrogenase mutations. Blood Cells Mol. 21: 64-67. 
Hutagalung et al.

Beutler, E. and Vullamy, T. J., 2002. Hematologically important mutations: glucose-6-phosphate dehydrogenase. Blood Cells Mol Dis.28: 93-103.

Bioron GmbH, Smart Molecular Biology Grade. 2012. Agarose 100 gram, molecular biology: manual. Catalog. No. S-604001. Rheinhorststr.18.67071. Ludwigshafen. Germany.

Clark, T.G., Fry, A.E, Auburn, S., Campino, S., Diakite, M., Green, A., Richardson, A., Teo, Y.Y., Small, K., Wilson, J., Jallow, M., Sisay-joof, F., Pinder, M., Sabeti, P., Kwiatkowski, D.P, Rockett, K.A. 2009. Allelic heterogeneity of G6PD deficiency in West Africa and severe malaria susceptibility. Eur J Hum Genet. 17: 1080-1085.

Carlos, A.G., Priscilla, W.G., Andrew, J.T., Abdisalan, M.N., Dave, L.S., Simon, I.H., Robert, W.S., 2008. The limits and intensity of Plasmodium falciparum transmission: implications for malaria control and elimination worldwide. Plos Medicine 5(2): 2-38.

David, L.S., Justin, M.C., Christinah, C., Geoffrey, J., Peter, W.G., Roly, G., Caroline, O.B., Ramanan, L., Simon, I.H. and Andrew, J.T.2013. A sticky situation: the unexpected stability of malaria elimination. Royal Society Publishing. 10: 2-13.

Dinas Kesehatan Propinsi Nusa Tenggara Timur. 2013. Profil Kesehatan Propinsi Nusa Tenggara Timur 2012-2013, Kupang. (no publication). Indonesia: 15-26.

Dinas Kesehatan Kabupaten Timor Tengah Selatan. 2014. Profile Kesehatan Kabupaten Timor Tengah Selatan 2012-2013. Nusa Tenggara Timur (no publication), Indonesia: 25-29.

Eijkman Institute, Kementerian Kesehatan Republik Indonesia dan Unicef. 2010. Diangnosis laboratorium malaria di Indonesia: petunjuk untuk peserta pelatihan. Eijkman Institute for molecular. Diponegoro, Jakarta: 15-27.

Elyazar, Iqbal R. F., Simon I. Hay and J. Kevin Baird., 2011a. Malaria distribution,
I.J. Biotech, Vol. 20, No. 2

Prevalence, drug resistance and control in Indonesia. Adv Parasitol. 74: 6-9.

Elyazar, Iqbal, R.F., Peter, W., Gething, Anand, P., Patil, Hanifah, Rogayah, Rita, K., Desak, M., Wismarini, Siti, N., Tarmizi, Kevin, B. and Simon, I.H. 2011b. malaria endemicity in Indonesia in 2010. Plos one 6. 21315: 8-12.

Faechem R. G., Philips A. A, Targett G. A, Snow R.W. 2010. Call to action: priorities for malaria elimination. Lancet. 376: 1517-1521.

Ganczakowski, M., Town, M., Bowden, D.K., Vulliamy, T.J., Kaneko, A., Clegg, J.B., Weatherall, D.J. and Luzatto L. 1995. Multiple Glucose-6-Phosphate Dehydrogenase-Deficient Variants Correlated With Malaria Endemicity in the Vanuatu Archipelago (Southwestern Pacific). Am.J.Hum.Genet. 56: 294-301.

Garmin International Inc, (2006) Global Positioning System (GPS) MAP Garmin 76 owner's manual. 1200 East $151^{\text {st }}$ Street, Olathe, Kansas 66062, USA: 2-4.

Gonzalo, J.D., Ari, W.S., Anup, A., Kevin, B., Germana, B., Pooja, B., Nick, C., Qin, C., Janice, C., Chi, E., Mark, F., Justin, G., Jimee, H., Marcus, L., Sarah, M., Didier, M., Francois, N., Issarang, N., Nwe, N.O., Pongwit, B., Wadchara, P., Kun, Q., Judith, R., Arantxa, R., Wichai, S., Siv, S., Lasse, V. and Lorenz, V.S. 2013. G6PD testing in support of treatment and elimination of malaria: recommendations for evaluation of G6PD test. Malarial Journal 12: 1-12.

Hay S. I., Okiro EA, Gething P. W, Patil A. P, Tatem A. J., 2010. Estimating the global clinical burden of Plasmodium falciparum malaria in 2007. Plos Med. 7(6): 2-9.

Heidi, R., Andrew, V., George, T., Andrew, J.T., Gerard, K., Ian, R., Ivor, H., Iata, H., Sam, L. and Archie C.A.C. 2010. Baseline spatial distribution of malaria prior to an elimination programme in Vanuatu. Malaria Journal. 9(150): 2-9.

HemoCue, AB. 2013. HemoCue Hb 201, operating manual.SE-262.23. Angelholm, Sweden: 3-8. 
Hutagalung et al.

Herdiana. H., Anis, F., Puji, B.S.A., Siti, Z., Risalia, R.A., Din, S., Hari, K., Maria, E.S., Titik, Y., Ali, I., Rahmadyani, Muhammad, Y., Rita, K., Siti, N.T., Ferdinand, J.L. and William, A.H. 2013. Progress towards malaria elimination in Sabang municipality, Aceh, Indonesia. Malaria Journal. 12(42): 3-10.

Howes, R.E., Frederic, B.P., Anand, P.P., Oscar, A.N., Peter, W.G., Mewahyu, D., Mariana, M.H., Katherine, E.B., Carmencita, D.P., Kevin, B.J. and Simon, I.H. 2012. G6PD deficiency prevalence and estimates of affected populations in malaria endemic countries: a geostatistical model-based map. PLOS Medicine 9(11): 1-15.

Jansen, G., Koenderman, L., Rijsen, G., Cats, B.P., Staal, G.E. 1985. Characteristics of hexokinase, pyruvate kinase, and glucose-6-phosphate dehydrogenase during adult and neonatal reticulocyte maturation. Am J Hematol. 20: 203-215.

KAPA Biosystems, (2013) Technical data sheet: KAPA HiFi PCR Kit. Boston, USA. 9: 1-4.

Kathy, L.B., Germana, B., Francois, N. 2010. The reality of using primaquine. Malaria Journal 9(376): 2-5.

Kementrian Kesehatan Republik Indonesia, (2010a) Penatalaksanaan kasus malaria di Indonesia. Direktorat Jenderal Pengendalian Penyakit dan Penyehatan Lingkungan (P2M\&PL), Percetakan Negara, Jakarta (no publication), Indonesia.

Kementrian Kesehatan Republik Indonesia. 2013a. Epidemiologi Malaria di Indonesia. Dirjen P2PM\&PL, Jakarta (no publication), Indonesia: 2-15.

Kementerian Kesehatan Republik Indonesia. 2013b. Malaria di Indonesia. Direktur Jendral Program Pemberantasan Penyakit Menular dan Penyehatan Lingkungan (P2M\&PL), Percetakan Negara, Jakarta (no publication), Indonesia: 5-10.

Kyoung, G.Y., Ji, S.Y., Shin, H.I., Moon, J.H., Cho, S.H., Lee, W.J., Kim, J.Y. 2014. First evaluation of glucose-6-phosphate
I.J. Biotech, Vol. 20, No. 2

(G6PD) deficiency in vivax malaria endemic regions in the Republic of Korea. Plos ONE 9(5): 1-10.

Lemeshow, S., Hoswer, J.R., Klar, D.W.J., Wanga, S.K. 1997. Samples size in (terjemahan) Besar Sampel dalam Penelitian Kesehatan. Yogyakarta, Indonesia: Gajah Mada University Press: 86-75.

Lorenz, V.S., Sarah, A., Fe Espino, Dennis, S., Qin, C., James, M., Kevin, B., Catherine, M., Rosalind, H., Didier, M., Germana, B., Ari, W.S., Lasse, S.V., Justine, G., Gonzalo, D., Shunmay, Y. and Ric, P. 2013. Review of knowledge gabs in glucose-6-phosphate dehydrogenase deficiency detection with regards to the safe clinical deployment of 8-aminoquinoline treatment regimens: a workshop report. Malaria Journal 12(112): 2-12.

Luzzatto, L., Metha, A., Vulliamy, T., 2001. Glucose-6-phosphate dehydrogenase deficiency. In the Metabolic $\mathcal{E}$ Molecular Bases of Inherrited Disease. 3: 4517-4553.

Macrogen. 2014. Standard sequencing ABI applied biosystem. 10-F. 254. Beotkkot-ro Geumcheon-gu, Seoul, Republic of Korea.

Maharaj, R., Natashia, M., Ishen, S., Philip, K., Devanand, M., Aaron, M., Eric, R. and Jaishree, R. 2012. The feasibility of malaria elimination in South Africa. Malaria Journal 11(423): 1-10.

Marina, C., Giuliana, G., Estella, O., Franco, T., Franca, M., Daniela, U., Gino, S., Lucio, L. and Paolo, A. 1998. Early Phagocytosis of Glucose-6-Phosphate Dehydrogenase (G6PDd) Erythrocytes Parasitized by Plasmodium falciparum May Explain Malaria Protection in G6PD deficiency. Blood. 92.7: 2527-2534.

Marla, K.J., Tamara, D.C., Denise, N.M., Philip, J.R. and Sunil, P. 2009. Impact of the method of G6PD deficiency assessment on genetic association studies of malaria susceptibility. Plos One. 4(9): 1-6.

Martin, B. 2000. An introduction to medical statistict (3rd edition). Great Clarendon street Oxford University Press, New York, USA: 185-192. 
Hutagalung et al.

Matsuoka, H., Meiji, A., Shigeto, Y., Indah, S.T., Suhintam, P., Henyo, K. and Fumihiko, K. 2013. Five Different Glucose-6-Phophate Dehydrogenase (G6PD) Variants Found Among 11 G6PD Deficient Persons in Flores Island, Indonesia. J. Hum Genet. 48: 541-544.

Mehdi, N., Noel, S.R., Andrew, C., Caterina, P.M., Sohail, R.R., Lori, L.J., Gregory, J.K., Mark, G., Oswaldo, L.C., Josef, T.P. and Victor, R.G.2010. Association of G6PD 292A, 376G with lower haemoglobin concentration but not increased haemolysis in patients with sickle cell anaemiaNational Institute of Health (NIH) Public Access. Br. J. Haematol. 150(2): 218-225.

Minucci, A., Kamran, M., Hwang, M.J., Cecilia, Z., Bruno, G., Ettore, C. 2012. Glucose-6-phoaphate dehydrogenase (G6PD) mutations database: Review of the "old" and update of the new mutations. Blood Cells, Molecules and Diseases, Elseviers 48: 154-165.

New England BioLabs Inc, (2013) G6PD deficiency variant enzyme. United Kingdom (UK).

Nguyen, M.H., Hideaki, E., Toshihiro, M., Takahiro, T., Francis, W.H., Ilomo, H., Nobuyuki, T. and Takatoshi, K. 2008. Glucose-6-Phosphate Dehydrogenase (G6PD) variant in East Sepik Province of Papua New Guinea: G6PD Jammu, G6PD Vanua Lava and a novel variant (G6PD Dagua). Tropical Medicine and Health 36(4): 163-169.

Nguyen, T.H., Jean, P.C., Tran, T.H.C., Nick, D., Jeremy, J. F., Tran, T.H. and Sarah, J.D. 2009. Glucose-6 Phosphate Dehydrogenase (G6PD) Mutations And Haemoglobinuria Syndrome In The Vietnamese Population. Malaria Journal. 8: 152-159.

Nick, C., Allan, P., Stephan, D. and John, N.W. 2011. Frequency of glucose-6phosphate dehydrogenase deficiency in malaria patients from six African countries enrolled in two randomized anti-malarial clinical trial. Malaria Journal. 10, 241: 2-9.
I.J. Biotech, Vol. 20, No. 2

Nicole, L., Maria, K., Marjorie, M., Brandon, T.L., Pooja, B., Sarah, M., Michael, K., Hao, Z., Huiqiang, H., Hui, J. and Gonzalo, J.D. 2014. Comparison of Quantitative and Qualitative Tests for Glucose-6-Phosphate Dehydrogenase Deficiency. American Society of Tropical Medicine and Hygiene. 91(4): 854-861.

Noor, A.M., Alegana, V.A., Patil, A.P. and Snow, R.W. 2010. Predicting the unmet need for biologically targeted coverage of insecticide-treated nets in Kenya. Am. J. Trop. Med. Hyg. . 83: 854-860.

Omumbo, J.A., Hay, S.I., Snow, R.W., Tatem, A.J. and Rogers, D.J. 2005. Modelling malaria risk in East Africa at high-spatial resolution. Trop. Med. Int. Health. 10: 557-566.

Promega corporation .2014. Wizard ${ }^{\circledR}$ genomic DNA purification Kit: instruction manual. Catalog No: A-1120. 2800 Woods Hollow Road. Madison. WI-53711-5399, USA: 1-3.

Promega corporation. 2015. Ethidium Bromide Solution. Catalog No. H-5041. 2800 Woods Hollow Road. Madison, WI-53711-5399, USA.

Rajendra, M., Natashia, M., Ishen, S., Philip, K., Devanand, M., Aaron, M., Eric, R. and Jaishree, R. 2012. The feasibility of malaria elimination in South Africa. Malaria Journal. 11. 423: 2-7.

Randox Laboratories Limited. 2013. Glucose-6-Phosphate Dehydrogenase Quantitative Test Manual. Ardmore, United Kingdom.Revision. 17: 1-4.

Ranjit, K. 1999. Research methodology. SAGE publication, India. Pvt. Ltd. 32. M. Block Market, Greater Kailash-1, New Delhi, 110048: 236-240.

Satyagraha, A.W., Arkasha, S., Venessa, B., Rosalie, E., Chase, R., Iqbal, E., Rintis, N., Farah, N.C., Alida, R.H. and Kevin, B.J. 2015. G6PD deficiency at Sumba in Eastern Indonesia is prevalent, diverse and severe; implications for primaquine therapy against relapsing vivax malaria. 10. 1371: 1-17. 
Hutagalung et al.

Smith, D.L., Smith, T.A. and Hay, S.I. 2009. Measuring malaria for elimination. Chapter 7 Shrinking the malaria map: a prospectus on malaria elimination. Santa Cruz (California): Malaria Elimination Group, Universitas of California Santa Cruz: 108-126.

Snounou, G., Viriyakosol, S., Jarra, W., Thaithong, S. and Brown, K.N. 1993. Identification of the four human malaria parasite species in field samples by the polymerase chain reaction and detection of a high prevalence of mixed infections. Mol Biochem Parasitol. 58: 283-292.

Supargiyono., Micheal, T.B., Mahardika, A.W., Inge, S., Dian, N., Royhan, R., Ayleen, A.K., Sulistyawati, William, A.H., Neil, F.L., Jackie, C. and Christ, J. D. 2013. Seasonal changes in the antibody responses against Plasmodium falciparum merozoite surface antigens in areas of differing malaria endemicity in Indonesia. Malaria Journal. 12. 444: 2-9.

Syafrudin, D., Krisin, Puji, A., Sekartuti, Rita, M.D., Farah, C., Ismail, E.R., Augustina, I.S., Elyazar, Iqbal, R.F., Awalludin, S., Agus, R., Michel, K. and William, O.R. 2009. Seasonal prevalence of malaria in West Sumba District, Indonesia. Malaria Journal. 8: 1-8.

Vivantis technologies Sdn, Bhd. 2012. DNA ladder and maker VC 100 bp. Selangor, Malaysia: 2-5.

White, N. J., Qiao, L.G., Qi, G. and Luzzatto, L. 2012. Rationale for recommending a lower dose of primaquine as Plasmodium falciparum a gametocytocide in populations where G6PD deficiency is common. Malaria Journal. 11: 418-425.

World Health Organization (WHO). 2014. From malaria control to malaria elimination. WHO press. Geneva: 7-35.

World Health Organization (WHO). 2014. "WHO Global Malaria Programme: World Malaria Report 2014. 20 Avenue mber 2015Appla, 1211 Geneva, Switzerland, : 24-35.
I.J. Biotech, Vol. 20, No. 2

World Health Organization (WHO). 2007. Malaria Elimination: A field manual for low and moderate endemic countries. 20 Avenue Appla, 1211 Geneva, Switzerland, : 24-35.

Goo, Y.K., Ji, S.Y., Shin,H.I., Moon, J.H., Cho, S.H., Lee, W.J. and Kim, J.Y. 2014. First evaluation of Glucose-6-Phosphate Dehydrogenase (G6PD) deficiency Vivax in malaria endemic regions in the Republic of Korea. Plos One 9(5): 2-6. 